\title{
Transparency of Land Administration and the Role of Blockchain Technology, a Four-Dimensional Framework Analysis from the Ghanaian Land Perspective
}

\author{
Prince Donkor Ameyaw *(i) and Walter Timo de Vries (1) \\ Land Management and Land Tenure, Technische Universität München (TUM), 80333 München, Germany; \\ wt.de-vries@tum.de \\ * Correspondence: aprincedonkor.ameyaw@tum.de
}

Received: 6 November 2020; Accepted: 2 December 2020; Published: 3 December 2020

\begin{abstract}
Existing studies on blockchain within land administration have focused mainly on replacing or complementing the technology for land registration and titling. This study explores the potential of using blockchain technology to enhance the transparency of all land administration processes using an integrative review methodology coupled with a framework analysis. This study draws on the Ghanaian land administration perspective to make this insightful. It appears possible to apply a permissionless public blockchain across all land administration processes. This integrates all departments, processes, and stakeholders of land administration to enhance openness, improve availability and accessibility to information, and foster participation for transparency simultaneously. This can change the transparency variation in land administration to be more equal and homogenous regardless of land type. This, however, depends on the standardization of processes across the divisions, as well as negotiation and consensus amongst all stakeholders, especially with chiefs. Limitations include: limited storage and scalability, as well as huge electricity consumption for operation. This study's policy implications are a review of all paper-based land transactions, a comprehensive digitization of land administration processes, public-private partnership on blockchain-based land administration, and professionals and stakeholder education on the technology.
\end{abstract}

Keywords: land administration; blockchain technology; land tenure; land valuation; land use planning; land development; Ghana

\section{Introduction}

Land administration involves 'the process of determining, recording and disseminating information about the relationship between people and land' [1] (p. 2), [2]. UNECE defined it as involving the recording and dissemination of information about ownership, value and the use of land, as well as the associated resources, while implementing the land management policies [3]. This relationship between people and land, and the functions performed with regard to ownership, value and the use of land require transparency. The transparency of land administration depicts the situation where land transactions and services are carried out in openness, and with maximum participation by all the concerned stakeholders [4]. Transparency allows for land tenure security [4-8]. Land administration transparency enables landowners and prospective purchasers to know the exact status of their land rights and interests, as well as the relation that they have with other individuals concerning pieces of land. This enhances peoples' confidence to invest in land which improves economic conditions [9]. Transparency is noted as one of the key principles for good land governance [10]. A good governance in land administration is beneficial to societies in diverse ways as it ensures: 
'Pro-poor support: rule of law is equal to all, and citizen has protected rights, Public confidence: greater public confidence, Economic growth: security of the land tenure and regulated transaction cost and taxation, Protection of state assets: legitimate use of state land for social and economic concessions, More effective and efficient public administration of land: formal market and reliable system, more revenue sharing for public services, Conflict prevention and resolution: equity, justice, and social stability' [9] (p. 13)

Nevertheless, land administration across the world lacks transparency and is corrupt everywhere [10]. Land administration systems are considered to be among the most corrupt institutions in the world [11]. UN-HABITAT in 2007 observed that land offices in most countries are among the most corrupt institutions [12]. Corruption exists where there is lack of transparency [4]. This lack of transparency in land administration begets numerous land challenges which include; land tenure insecurity, high cost of land transactions due to informal payments, reduced private sector investment in land, less revenue for the state, increased land grabbing by officials, increased land conflicts, landlessness, and inequity in land distribution. These challenges promote social instability, exclusion and political instability through land conflicts, land poorness and landlessness. The situation leads to disregard for the ethics and standards of behavior as land titles, building permits and zoning regulations become no longer trusted by citizens $[4,7,8]$. These outcomes inhibit the overall development of societies. Most countries, particularly in Africa, face stunted development and impoverishment as land dominates the economy, and provides livelihoods to the majority of the continent's population [13]; thus, the focus of this study is from an African country's perspective. The need for the transparency of land administration has not received the needed attention in years past as [9] notes that the attention to the issue of transparency in land administration and land governance is recent.

In recent years, many studies on ways to enhance the transparency of land administration have shifted attention to the potentials of blockchain technology [11,14-17]. Blockchain is identified to enhance transparency in land administration processes and or functions though the integration of all land stakeholders, in a way that allows each stakeholder to be aware of, and to be involved in land transactions without intermediaries (land administration processes and functions have been used synonymously and interchangeably in this study). Blockchain helps to improve trust in the system and to enhance the confidence of citizens in the land administration system [17]. It is identified that despite the digitization of land records and diverse web applications, the system for land records management is weighed down by various kinds of errors and inconsistencies as well as a lack of transparency [18], the same problems which blockchain technology potentially eliminates [19]. Countries like Georgia, and Sweden, among others, have piloted blockchain technology to land administration and reported the successful outcomes of improved transparency and enhanced citizens' trust in the land institutions [20]. Several studies on the application of blockchain technology for land registration and land titling exist to show the potential of blockchain technology to improve transparency in these land administration processes $[17,20-25]$. These show the surging interest in blockchain technology in land administration. However, despite the rising interest in the potential of blockchain in land administration [19], there is to date no studies that have holistically assessed the transparency of all the processes of land administration, and how blockchain technology can help improve these. The existing studies mainly focus on land registration, and titling $[14,17,20-22,25-29]$. These, however, only fall under the land tenure processes and or functions [30]. Other land administration processes-including land value, land use planning, and land development-have not been sufficiently explored, if any, in order to see how blockchain technology can enhance the transparency of these processes and in a simultaneous way. This leaves a research gap. To focus only on land tenure processes and to conclude that blockchain technology enhances the transparency of land administration is to miss the vast land administration processes of land value, land use planning, and land development. This leads to missing the broad concept of land administration transparency. This also presents a challenge to aptly conceptualize blockchain technology and the transparency of land administration, and hence, this study aimed to fulfil this research gap. This study argues that understanding the transparency of land administration and the 
role of blockchain technology in this regard becomes incomplete if the processes of land administration are not holistically considered. To this end, this study was guided by these objectives:

1. To identify the essential elements and relations between blockchain technology and the transparency of land administration in the existing literature;

2. To assess the potential of blockchain technology to improve the transparency of land administration functions-based on the Ghanaian land administration context.

These objectives are particularly important as they fill a literature gap by looking at what transparency actually means in land administration discourses, and how the widely accrued technology of blockchain could potentially contribute to achieving this. Secondly, it helps in extending the literature on the potential of blockchain technology in the specific context of land administration in a more comprehensive approach. The paper starts by explaining the methodology applied to address both research questions. The subsequent section presents the elements and relations between blockchain technology and land administration processes and applies this from the Ghanaian perspective. The section that follows afterwards discusses the possible roles blockchain technology could play in enhancing or affecting the transparency of land administration processes. The final section reflects on the study's guiding framework and derives policy recommendations.

\section{Materials and Methods}

\subsection{Research Approach and Boundaries}

The novelty of blockchain's application in land administration opens it up for new discourses on its potentials to land administration. On this basis, more research studies are needed as conceptualizations and theoretical models in this regard are still preliminary. Methodologically, an integrative review is considered appropriate for such new topics as compared to a systematic, and semi-systematic review methods [31]. Given this, we apply a review methodology based on an integrative interpretation process of existing documentation and literature, with the aim of deriving an alternative conceptualization of transparency in land administration. Such an integrative literature review methodology is suitable when investigating the extent to which a new concept or technology fits in a new context. This approach has also been used in similar studies [32,33]. Furthermore, it is suitable for new and emerging topics that have not benefited from a large body of literature and conceptualizations [31]. Integrative reviews assess, critique, and synthesize existing literature on a topic in ways that evoke new theoretical frameworks, and perspectives [32,34]. Integrative reviews can follow rationalist theory as an appropriate epistemology and are based on an exploratory research design which deducts the scientific knowledge and new perspectives through the critical review, analysis and synthesis of existing literature [31,35,36]. According to [36], integrative literature review methodology, compared to systematic, and semi-systematic review methodologies offers a better opportunity to assess pending developments in a field and to identify factors that are shaping the future of ideas or issues in that field through critiquing, and analyzing relevant literature [31]. Doing this, however, requires prior understanding and knowledge on the topic to guide and facilitate the critique, analysis, and appraisal of existing relevant literature and concepts [35]. In this way, integrative review aids in identifying relationships, gaps, deficiencies, and opportunities for improvement on existing literature and concepts, thereby offering a possibility for rethinking the topic and improving scientific knowledge by extension (update) and or reconceptualization [31]. However, integrative review analysis is criticized for not being developed in accordance with any specific standard and is mostly not truly integrative but a mere summary of existing studies. This can lead to a lack of rigor as compared to systematic reviews $[32,34]$. The research underlying this paper overcame these potential critique points by employing and combining the method with the framework analysis (sometimes also referred to as qualitative content analysis). This provides a structured approach to analyze the main concepts and ideas which reveal relationships, divergences and gaps for critiquing, leading to a better synthesis of both the emerging perspectives and existing literature in a rigorous way [37]. 
Following the study objectives of identifying the conceptualization and relations in blockchain technology and land administration, and the potential of blockchain to enhance the transparency of land administration, a conceptual organizational structure of integrative literature review is used [31]. In this, the main concepts of the topic provide a framework around which the review is organized to help ensure coherence and clarity on what is being reviewed, and how the concepts of the topic enjoin into a unified idea [31]. In order to find contextual boundaries, the literature review focused on documents which specifically addressed ongoing research and practical advantages and disadvantages of blockchain in the context of land administration. The framework analysis creates a new structure for findings that help to summarize them in a way that supports answering the study questions [37]. This provides a clear stepwise approach to follow which produces a highly structured output of summarized findings and gives a holistic, descriptive overview that allows for easy critiquing and analysis [37]. The study's literature is not constrained by spatial and temporal boundaries. This allowed for the geographically unlimited literature review of all available and relevant data, from empirical, and review (secondary) literature in the English language in which a large volume of literature on the topic was found. This is not to conclude that literature did not exist in other languages, but the majority of returned literature was in English. Additionally, English is the language that the authors have mastery knowledge of. No linguistic biases were intended. The literature identification process and sources, review, analysis, synthesis, modelling/reconceptualization, and means of scientific knowledge extension on the topic follows in the next section and is summarized in Table 1 below. 
Table 1. Research process and design overview.

\begin{tabular}{|c|c|c|c|}
\hline & Steps & Activities & Output \\
\hline 1 & Setting study boundaries & $\begin{array}{l}\text { Outlining spatial and geographical limits, language boundary, concepts under } \\
\text { focus, and literature type and publication timeframe }\end{array}$ & $\begin{array}{l}\text { - No geographical and spatial limitations. } \\
\text { - } \quad \text { Only data in English language were considered. } \\
\text { - Focus centered on land administration processes and } \\
\text { functions, and transparency, and blockchain's application } \\
\text { in land administration. }\end{array}$ \\
\hline 2 & $\begin{array}{l}\text { Literature identification: } \\
-\quad \text { search strategy } \\
-\quad \text { selection } \\
-\quad \text { literature sources } \\
-\quad \text { validity and reliability }\end{array}$ & $\begin{array}{l}\text { Systematic literature search and spider backward search strategies. Direct typing } \\
\text { into databases, the keywords and phrases like, land administration, land } \\
\text { administration functions, land administration transparency, blockchain and land } \\
\text { administration, blockchain for land registration, and blockchain and land } \\
\text { transparency, and using their different combinations. } \\
\text { - Focus on land administration functions or processes, transparency of land } \\
\text { administration, and blockchain's application to land administration. } \\
\text { - Scientific online databases including Google Scholar, Elsevier, Springer Link, } \\
\text { Scopus, JSTOR, Research Gate, Web of Science, and Taylor \& Francis. } \\
\text { - Using different synonymous keywords and phrases, and their combinations across } \\
\text { different scientific databases helped to check validity and reliability. }\end{array}$ & $\begin{array}{l}\text { Total search results }=195 \text { online publications. } \\
\text { - } \\
\text { - }\end{array}$ \\
\hline 3 & Initial literature review & Titles and abstract reading. & $\begin{array}{l}\text { - Elimination of duplicated documents, and documents } \\
\text { that did not meet the study focus, and boundaries. }\end{array}$ \\
\hline 4 & $\begin{array}{l}\text { Detailed integrative review: } \\
-\quad \text { critical review } \\
-\quad \text { analysis } \\
-\quad \text { synthesis }\end{array}$ & $\begin{array}{l}\text { - Detailed and critical full text reading. } \\
\text { - } \quad \text { Use of concept structure and framework analysis. } \\
\text { Through textual narratives and visualizations techniques (framework diagrams, } \\
\text { tables, procedural diagrams) the main ideas, themes, patterns, gaps, and } \\
\text { relationships were categorized, and summarized. } \\
\text { Based on logical and deductive reasoning, the analysis and synthesis of emerging } \\
\text { knowledge was made. }\end{array}$ & $\begin{array}{l}\text { - } \quad \text { Theoretical basis of blockchain technology. } \\
\text { - } \quad \text { Main potentials of blockchain technology. } \\
\text { - Main land administration processes in Ghana and the } \\
\text { challenges/gaps. } \\
\text { Potential relation between blockchain technology and } \\
\text { transparency in the land administration processes. }\end{array}$ \\
\hline 5 & Topic reconceptualization & $\begin{array}{l}\text { The use of rationalist theory of knowledge generation, logical, and deductive } \\
\text { reasoning, and the authors' primary knowledge on the topic, new knowledge was } \\
\text { created and implications explained. }\end{array}$ & $\begin{array}{l}\text { Ways of blockchain application to enhance transparency } \\
\text { in all land administration processes of land tenure, land } \\
\text { valuation, land use planning, and land development. }\end{array}$ \\
\hline 6 & Conclusion and recommendations & $\begin{array}{l}\text { - } \quad \text { Study contribution to knowledge. } \\
\text { - } \quad \text { Areas of further research, and implications for practitioners, and policy makers. }\end{array}$ & $\begin{array}{l}\text { Extension of blockchain's potential to support land } \\
\text { administration beyond just land tenure processes. } \\
\text { - } \quad \text { Revealing a new area for further research. } \\
\text { - Explaining new knowledge's implication for practice and } \\
\text { policy making. }\end{array}$ \\
\hline
\end{tabular}




\subsection{Data Sources and Research Methods}

The literature search was carried out systematically based on the main concepts and ideas in the topic using keywords, and phrases like, land administration, land administration functions, land administration transparency, blockchain and land administration, blockchain for land registration, blockchain and land transparency, land tenure, land valuation, land use planning, and land development. These keywords and phrases were searched for across different scientific databases including Google Scholar, Elsevier, Springer Link, Scopus, JSTOR, Research Gate, Web of Science, and Taylor \& Francis. Searching with diverse synonymous keywords and phrases across the different scientific databases facilitates access to a large volume of documents on the topic and allows for a validity, and reliability check. The systematic literature search resulted in 102 documents on land administration. This number was based mainly on documents' titles and how they related to the land administration processes; land registration, land information, land valuation, land taxation, land use planning, and land development. This selection was based on sampling and is not considered to be representative of all land administration systems but for Ghana. This is because, although some general documents on land administration processes were considered, the main focus was on land administration processes from the Ghanaian perspective, and hence, more of the documents relating to this context were considered. Moreover, 26 documents on land transparency, 42 on blockchain's application in land administration and nine on the methodological approach, making a total of 179 retrieved documents. The initial critical reading of the documents' titles and abstracts in some instances, while being guided by the research boundaries, resulted in 81 documents for the detailed and critical full text reading and review. The full text reading helped to identify the extent to which the documents discussed the topic and revealed the missing gaps. A spider backward search strategy helped to find additional sources. Through the spider backward approach, new citations and references that come up in the full text reading of selected literature and have relevance to the study are traced back to their original documents for identification and review. This strategy resulted in 17 additional online documents making it a total of 195 documents in all. The spider backward retrieved documents were also subjected to review based on the study boundaries. In the end, 98 documents in total were critically reviewed and 76 accepted and used for this study.

Based on conceptual organizational structure, and the framework analysis approach, the main ideas were categorized under different broad themes of blockchain technology, and the transparency of land administration processes using text narratives and visual models, which are suitable for integrative literature analysis and synthesis [31]. This approach helped to compile the main ideas from the reviewed studies, and also evidence-based documented practical applications of blockchain, which were all used to summarize and synthesize the study findings with respect to the research objectives [38]. Abstractive textual and narrative modeling based on the rationalist theory, deductive reasoning, and the authors' knowledge on the topic were used to establish the potential relationship in blockchain technology and the transparency of the land administration functions. The rationalist approach guided the justification and explanation of this potential relationship. The implications of the new and extended scientific knowledge to existing literature, practitioners and policy makers is explained, the study limitation highlighted, and suggestions for future research directions made.

\section{Results}

\subsection{Theoretical Basis of Blockchain Technology and Its Operation}

Blockchain technology refers to a fully distributed crypto-graphical system that captures and stores a consistent, immutable and linear event log of the transactions between networked actors [39]. Blockchain technology allows for managing the records of transactions without a central server or authority [28]. Through this network, which is made of computers (for stakeholders) that operate on a blockchain system to execute transactions and are termed as 'Nodes', blockchain technology works, based on what is technically referred to as 'Blocks and Hashes'. In blockchain's operation, transaction 
data are stored in digital containers called 'blocks'. The first block created is termed as the genesis block [40], and each block after it is created is linked to a parent block (the preceding block) through unique digital fingerprints termed as 'hashes' [14]. This is shown after Figure 1. The hashes are time-stamped in a header at the top of each block of information to give certainty on the order of transactions' creation. After creating a transaction, and before it is accepted onto the blockchain system, the majority of the nodes will have to verify and validate that it is accurate and authentic as exists in reality on the ground. This verification and validation process is done through a system termed as 'consensus mechanism' [1]. Once transactions are validated and accepted onto the blockchain system, the information in the blocks becomes immutable and resilient against tampering or falsification. In this way, not even the one that created it can manipulate the data; and, the transaction with its data can be accessed at any time by all stakeholders, which allows for transparency $[16,20,41]$. As compared to other land transaction management tools like modeling, database management, and workflow management, there are three main arguments for why the blockchain technology is considered a solution with great benefits and possibly no alternative. First, in blockchain land transaction, records, certificates, and digital IDs, cannot be manipulated. Second, there can be no double spending/sales of land since any purported attempt is automatically known to all stakeholders [42], and thirdly, land transaction rules and requirements can be embedded into the blockchain's 'smart contract' application which makes it difficult for anyone to manipulate the process, and it also reduces human error possibilities [16]. Smart contracts are blockchain applications which allow for a pre-programming of a contract by defining all the conditions and requirements, and when parties have met these conditions and requirements, the contract is executed automatically. The blockchain transaction steps are:

1. A node/stakeholder with an account signs digitally and initiates the transaction;

2. A timestamp is added to prove the time of transaction creation;

3. Transaction is broadcasted by decentralization to all other nodes on the network;

4. The transaction is mined ("which involves validation of a set of transactions (block) in the network by means of showing the computational proof of the work done") [24] (p. 20), by one of the nodes. After this, it is verified and validated as authentic, or declined if it is found otherwise by the majority of the nodes based on a consensus mechanism;

5. The validated transaction is then recorded in a new block and hashed to the previous block to form the chain of blocks as is shown after Figure 1.

Technically, three processes are identified in how a blockchain works. Digital time-stamping, distributed verification, and cryptographic hashing [43]. Figure 1, below, shows the blockchain transaction process, Figure 2 shows the blockchain structure, and Table 2 shows the inherent elements that make the blockchain beneficial to land administration transparency. 


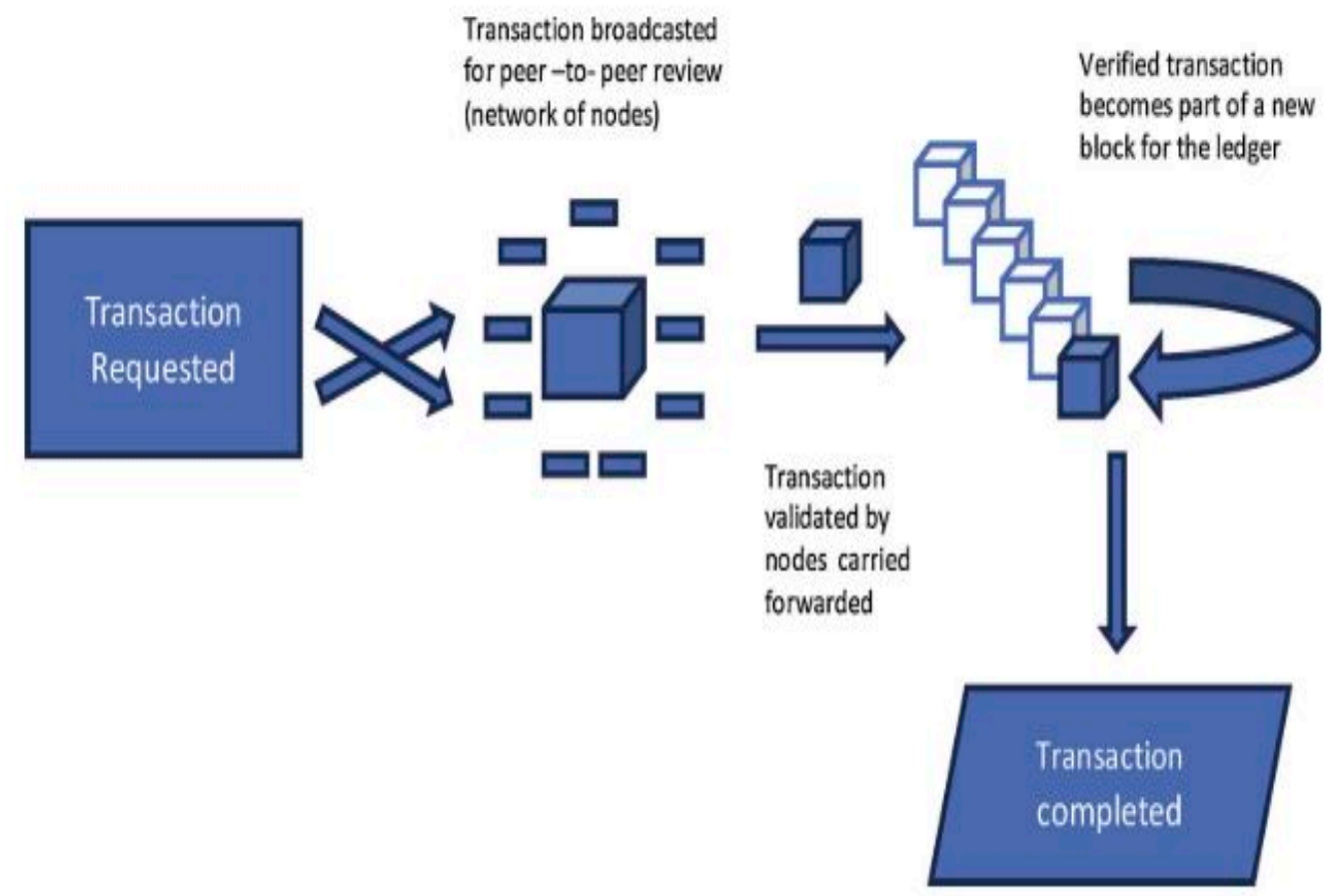

Figure 1. Blockchain transaction process. Source: [23].

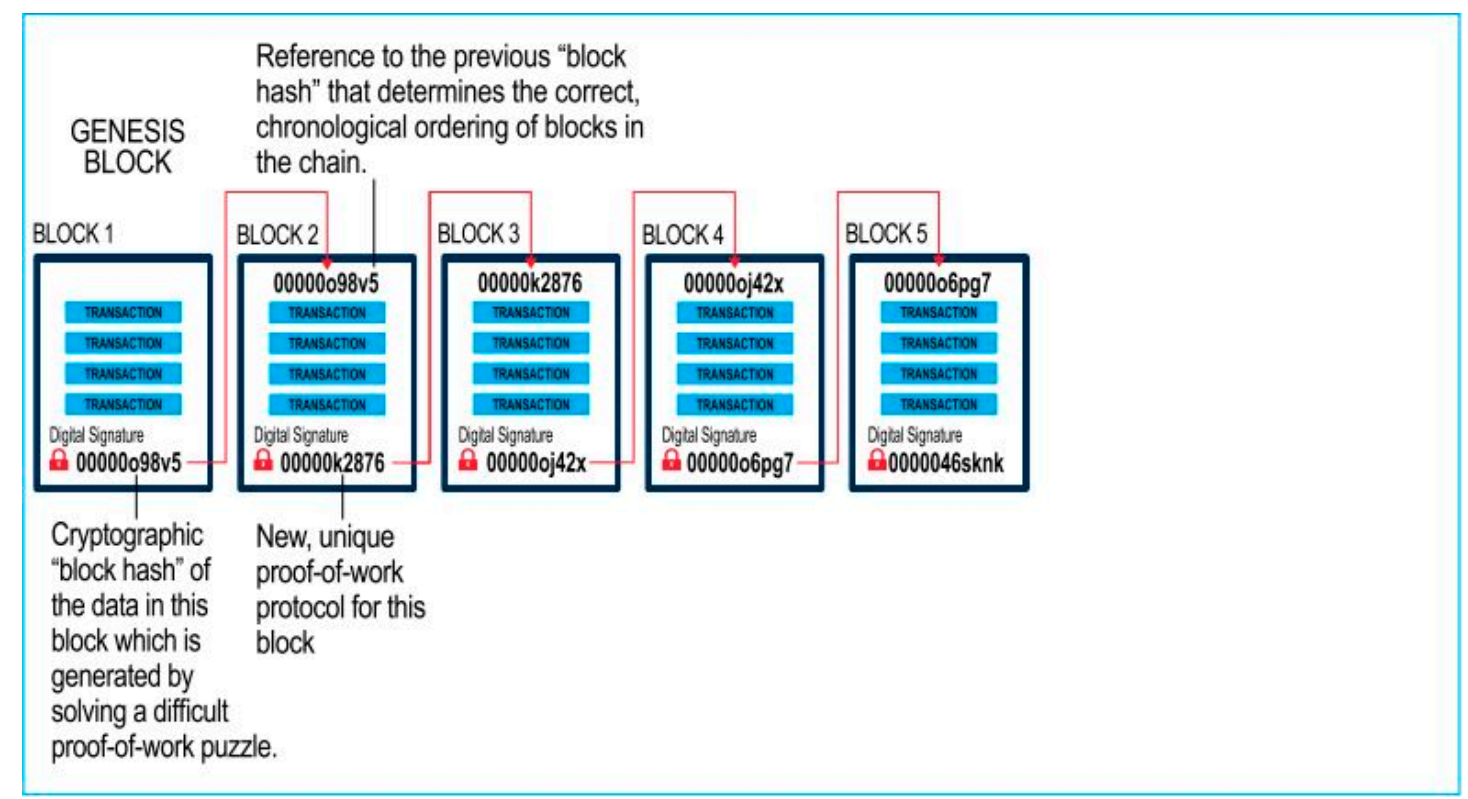

Figure 2. Blockchain structure. Source: [40]. 
Table 2. Blockchain potentials to land administration Source: authors' construct.

\begin{tabular}{|c|c|c|}
\hline Potential Benefits of Blockchain & Elements that Make It Possible & References \\
\hline Transparency & $\begin{array}{l}\text { Decentralization of transactions across all nodes (stakeholders), possibility for evaluating the } \\
\text { authenticity of the transaction by all stakeholders, and the access to all transactions and their } \\
\text { historical records by all stakeholders. }\end{array}$ & {$[10,20,23,28,29]$} \\
\hline Eliminating fraud and double sales & $\begin{array}{l}\text { Decentralization-once a transaction has been completed, all stakeholders have copies and any } \\
\text { further action on the transaction is known to the stakeholders. A second attempt to resell the land } \\
\text { will be known to all stakeholders and therefore the transaction will not be validated since it has } \\
\text { already been sold to another person. }\end{array}$ & {$[1,10,11,17]$} \\
\hline Enhancing trust & $\begin{array}{l}\text { Immutability and consensus mechanism-immutability of blockchain coupled with the consensus } \\
\text { mechanism by majority stakeholders helps prevent manipulation of land data, as well as } \\
\text { misrepresentation of land data in the system. }\end{array}$ & {$[1,20,23,26,44]$} \\
\hline Establish clear ownership & $\begin{array}{l}\text { Hashing - the existence and access to the historical facts on the transaction made possible by } \\
\text { hashing allows ease in establishing the ownership status as well as all encumbrances. }\end{array}$ & [17] \\
\hline Eliminating corruption & $\begin{array}{l}\text { Smart contracts-land transactions based on and carried out using smart contracts helps to } \\
\text { eliminate all forms of corrupt deals since all the procedures involved in the transaction are clear and } \\
\text { can be carried out without human intervention thus leaving no room for corruption. }\end{array}$ & [20] \\
\hline Eliminates manipulation & $\begin{array}{l}\text { Decentralization and immutability—due to the distributed copies of transactions available to all } \\
\text { nodes; and the difficulty to change blockchain data, any purported unauthorized changes or } \\
\text { manipulation will be detected by all the stakeholders and will accordingly be declined or denied. }\end{array}$ & {$[10,23]$} \\
\hline Easy information access & $\begin{array}{l}\text { Decentralization-information stored is available to all the nodes at all times. This enhances the } \\
\text { ease of access to land transaction information as there are no intermediaries. }\end{array}$ & {$[20,23,44]$} \\
\hline Data quality, accuracy and integrity & $\begin{array}{l}\text { Consensus mechanism-the verification and validation process inherent to the system ensures that } \\
\text { the information accepted on the blockchain corresponds with reality on the ground. Any } \\
\text { inconsistencies, and inaccuracies will lead to the rejection of the transaction. }\end{array}$ & [23] \\
\hline Enhances high participation by all stakeholders & $\begin{array}{l}\text { Decentralization-stakeholders become involved in the transaction at every stage due to the } \\
\text { decentralized distribution across all the nodes. This allows all stakeholders to know about the } \\
\text { transaction and to partake in it through the consensus mechanism. }\end{array}$ & {$[1,23,26,45]$} \\
\hline Reduced human error possibilities & $\begin{array}{l}\text { Smart contracts for land transactions help eliminate human involvement as all required actions } \\
\text { necessary for carrying out transactions have been pre-programmed. Once a step is completed, the } \\
\text { transaction moves to the next step without human actions until it is completed. }\end{array}$ & [10] \\
\hline Security and resilience & $\begin{array}{l}\text { Decentralization and distribution-due to the decentralized and distributed functionality, data are } \\
\text { stored in multiple databases of different stakeholders which are tamper proof, immutable and } \\
\text { encrypted. It is thus difficult to hack all the different databases at the same time. }\end{array}$ & {$[11,15,24]$} \\
\hline
\end{tabular}


The elements of the blockchain identified in Table 2 are reflected in the discussion section on how they help to achieve the transparency of the land administration.

It is important to point out that there are two main architectural categorizations of blockchain technology based on access and use possibilities. These are the public and private blockchain. These are further categorized into permissioned, and permissionless blockchains. The public and private categorizations determine who can access and read from the blockchain ledger, while the permissioned, and permissionless categorization determines who is able to introduce a transaction, and also participate in the consensus mechanism $[16,46]$. It is therefore important that the right blockchain architecture is selected depending on the purpose of application. Table 3 below shows the accessibility and use possibilities available in the different blockchain architectures.

Table 3. Blockchain architectural categorization Source: adopted from [16].

\begin{tabular}{|c|c|c|c|c|}
\hline & \multicolumn{4}{|c|}{ Blockchain Architectural Categorizations } \\
\hline & \multicolumn{2}{|c|}{ Public Blockchain } & \multicolumn{2}{|c|}{ Private Blockchain } \\
\hline & Permissionless & Permissioned & Permissionless & Permissioned \\
\hline Participants & Anonymous & Identified & Identified & Identified \\
\hline Data accessibility & Anyone & Anyone & $\begin{array}{l}\text { Authorized } \\
\text { participants }\end{array}$ & $\begin{array}{l}\text { Authorized } \\
\text { participants }\end{array}$ \\
\hline $\begin{array}{l}\text { Initiating } \\
\text { transactions }\end{array}$ & Anyone & $\begin{array}{l}\text { Authorized } \\
\text { participants }\end{array}$ & $\begin{array}{l}\text { Authorized } \\
\text { participants }\end{array}$ & $\begin{array}{c}\text { Network operator } \\
\text { only }\end{array}$ \\
\hline $\begin{array}{l}\text { Participation in } \\
\text { consensus } \\
\text { mechanism }\end{array}$ & Anyone & $\begin{array}{l}\text { Authorized } \\
\text { participants }\end{array}$ & $\begin{array}{l}\text { Authorized } \\
\text { participants }\end{array}$ & $\begin{array}{l}\text { Network operator } \\
\text { only }\end{array}$ \\
\hline Network types & Decentralized & $\begin{array}{c}\text { Partly } \\
\text { decentralized }\end{array}$ & Hybrid & Centralized \\
\hline
\end{tabular}

Some writers have advocated for the adoption of a private blockchain for land administration, specifically for land registration [44]. However, given the architecture categorizations in Table 3, this study considers a permissionless public blockchain more suitable for a land administration system. This is because, permissioned blockchains invade privacy/data protection policies with or without participants' consent since it allows participants to be automatically identified. Moreover, permissioned blockchains 'lose their decentralized, open nature, and become less transparent and more centralized', [47] (p. 152). These create difficulties in land data accessibility, lead to a lack of trust due to centrality and refute the transparency objective required in land administration. Public permissionless blockchain on the other hand helps to adhere to privacy/data protection policies. The anonymity of participants prevents the breach of privacy policies. In land administration, however, the question of who has what rights and to which land parcel is very critical, and therefore makes it important to be able to know participants' identity. To address this, a public permissionless blockchain has a way to allow participants' identity to be known where required. In [47], the authors noted that, in the public permissionless blockchain, although the users' identity is encrypted and hidden, there exists a possibility that in certain contexts, the identity of the participants can be inferred based on transaction patterns or other markers. This possibility helps to make inferences to participants and their actions whenever the need be, particularly where transactions or actions might appear suspicious. These functional possibilities of the public permissionless blockchain compared with the other architecture types make it more suitable for a public land administration system like the case in Ghana.

Notwithstanding these potentials and possibilities of blockchain enumerated, the technology, like any other technology, has its own flaws and or restrictive factors which must be taken into account before the decision to adopt and implement it. Generally, blockchain is criticized due to its limited storage capacity. Current public blockchains are unable to handle large volumes of land data such as 
deeds, titles, and maps [48]. This could cause problems in land administration since land transactions and data transactions occur daily. The authors in [17], however, recommend that an external storage for blockchain's smart contracts and documents can be created to support the system-see [17] for further details. Another challenge is scalability. Due to its nascent nature, and storage capacity limitation, there are challenges to scalability of the technology, particularly with increasing volumes of data and workload. This equally affects the speed of the system [47]. Moreover, blockchain technology consumes a huge amount of electricity, and this could be a potential challenge for some developing countries that do not have an equally huge electricity supply. Other adoption considerations of blockchain impede upon technological know-how. Blockchain in land administration is recent and immature [47]. Many land professionals are therefore not conversant with the use of the technology. It is important, therefore, to train professionals prior to blockchain adoption to be able to understand and use the technology. Finally, blockchain operation requires strong computational power and efficiency [49], coupled with strong and stable internet connectivity to be able to perform efficiently. These have to be considered in deciding on blockchain adoption.

\subsection{Summary Overview of Land Administration Processes in Ghana}

In assessing the extent to which transparency exists in a land administration system, it is important to know and recognize the differentiations and variations of the land administration processes. It is mainly assumed that the collective degree of transparency of each of the respective processes constitutes the variation of transparency of land administration as a whole. In [50], a land administration system is defined as a formal system that is used to locate and identify a real property, and to keep the records of past and current data regarding the ownership, value and use of that property. This definition is found to be suitable in this study's context as it highlights the different processes of land administration: land tenure, land valuation, land use planning, and land development. Few studies exist on the transparency of land administration in Ghana, and these have somewhat touched upon transparency issues in individual land administration processes of either land tenure, land valuation, land use planning, or land development $[35,49,51-53]$. No single study has concurrently assessed all processes of land administration, and the possibility of achieving a simultaneous transparency in these processes-which leaves a gap where data and research are missing. However, land administration, according to [54], must fulfil land title issuance, land taxation, land transaction registrations, changes in land use, resolving land disputes and handling complaints, and facilitate spatial and land use planning. These processes fall under the four broad land administration processes of land tenure, land value, land use planning, and land development [30]. This study thus argues that achieving a simultaneous transparency in all four main land administration processes has intrinsic and synergistic benefits that outweigh pursuing transparency in the individual processes separately. This is shown in Section 4 which comprehensively discusses the different land administration processes, and blockchain's potential to support and to achieve a simultaneous transparency across these processes.

\subsubsection{Land Tenure Processes}

Land tenure processes border on the land registration activities of securing and transferring rights in land and natural resources [55], and also on land information infrastructure. In these processes, [30] notes that land registration by means of land register establishment, creation of accessible land records, land transaction procedures, and the processing of information are the matters of interest. Land registration involves a process of the official recording of rights to land through deeds or titles aimed at supplying legal security to the right holders and potential buyers [56]. The sequence of the land registration process in Ghana is summarized in Figure 3 below. For details, see [57-59].

From an actor network theoretical (ANT) view point, Figure 3 below can best be understood not only based on the connection between the different divisions, but also, by the type of communication technology that connects these divisions and their work processes together. ANT helps to analyze the way in which actors (both human and non-human) build and maintain networks [43], for the purpose 
of achieving a goal. ANT is broadly advocated for in development research works particularly those focusing on technology. This is because, in a practical sense, 'there is ever-greater use of networks of individuals and organizations to deliver development and an ever-greater role for the material (especially technology) in development processes' [43], p. 38]. In the context of this study therefore, ANT theory gives a sound theoretical basis for understanding the different land administration processes, performed by the different land divisions, and stakeholders, and the role of blockchain technology in this relation towards achieving land administration transparency.

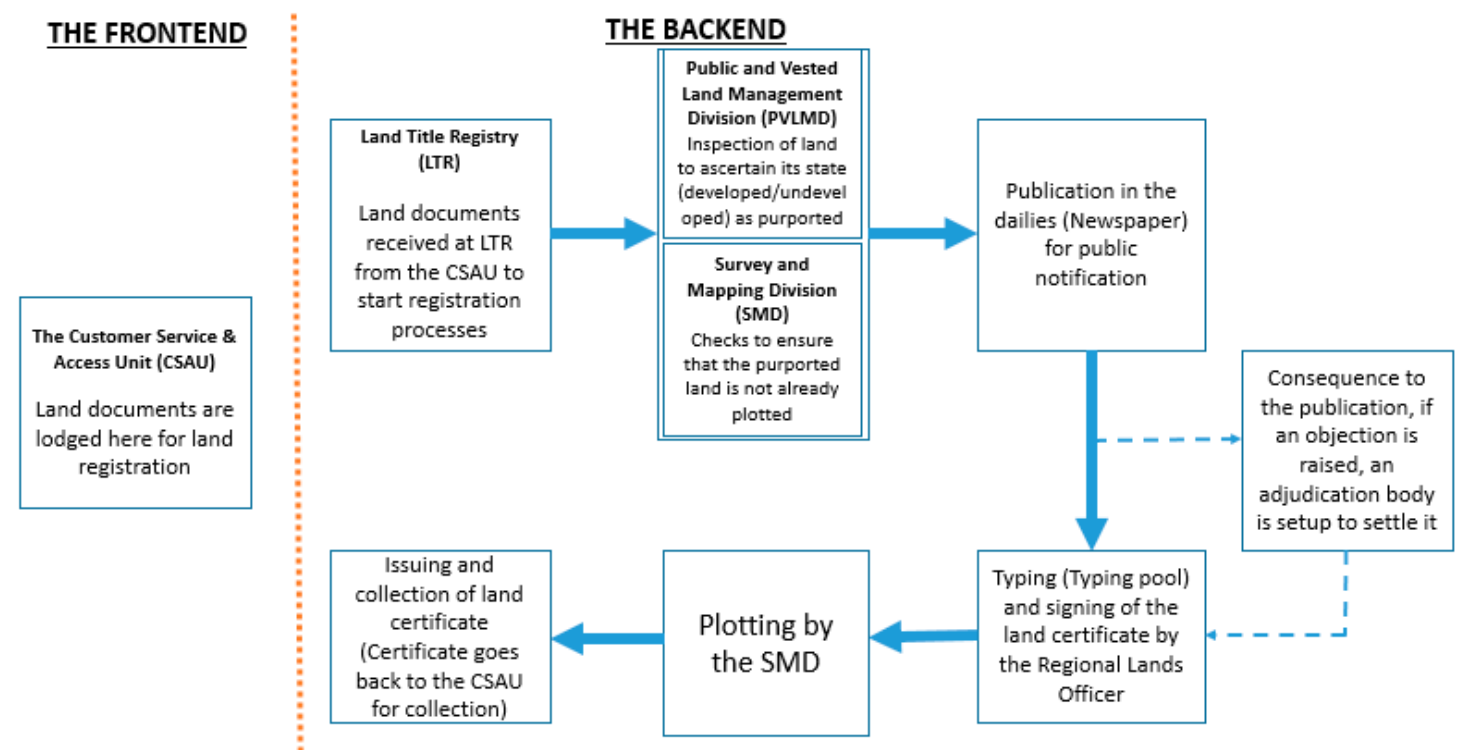

Figure 3. Land registration process. Based on $[57,58]$.

From Figure 3 above, the frontend (Customer Service and Access Unit (CSAU)) serves as the intermediary between clients and the lands commission. Clients visit and submit their land documents, or complaints on any land process to the frontend desk of the CSAU. The CSAU, after certifying the documents, relays these to the right divisions at the backend, be it (LTR, PVLMD, or SMD). For land registration specifically, the CSAU first relays land documents to the LTR, from where it goes through all the formal processes with the different divisions until completed, brought back to the CSAU, and clients invited to pick up their certificates. Although other additional departments, such as the Land Valuation Division (LVD), are involved before land can be successfully registered, Figure 3 above is a simplified process which is understandable since the LTR is the first and last department involved in the registration process [58]. Other incidental activities include the submission to and stamping of land documents at the LVD before acceptance for registration, and also the settling of any objections that might be raised upon the publication in the dailies. However, when all documents are found correct and no objections raised, the above process should take on average 3-5 months to complete, but depending on individual cases and circumstances, certain cases could take longer [58].

Land information infrastructure on the other hand is concerned with the cadastral and topographic datasets [55].

\subsubsection{Land Valuation Processes}

The main processes considered here are the valuation and taxation of land and properties [55]. Valuation is an estimate or opinion of value based on expertise to meet the supply and demand under certain conditions. These conditions may be subjective or objective depending on the context of the valuation [60]. Valuation must be an unbiased estimate or opinion, a knowledgeable or learned opinion of value, and a supported estimate of a defined value. The value must represent a reasonable market value which according to the 2017 International Valuation Standards Council's (IVSC) definition. is 'the 
estimated amount for which an asset or liability should exchange on the valuation date between a willing buyer and a willing seller in an arm's length transaction, after proper marketing and where the parties had each acted knowledgeably, prudently and without compulsion' [48] (p. 4), [30] (p. 4). There are five different methods for asset valuation, namely (1) the market approach or comparative method, (2) the income approach or investment method, (3) the residual approach or development method, (4) the profit method, and (5) the cost approach or contractor's method, see details in [48]. The choice of a method relies on three aspects, the nature of the asset, the basis of the valuation, and the purpose of the valuation [60]. The nature of the asset is concerned with the physical properties, characteristics and conditions of the asset. The basis of the valuation may include, market value or the market rent, worth and investment value, and fair or equitable value, while the purpose for the valuation may also include, for sale and purchase, rental, mortgage, insurance, compensation, and lease [48]. Figure 4 below shows the valuation process in Ghana.

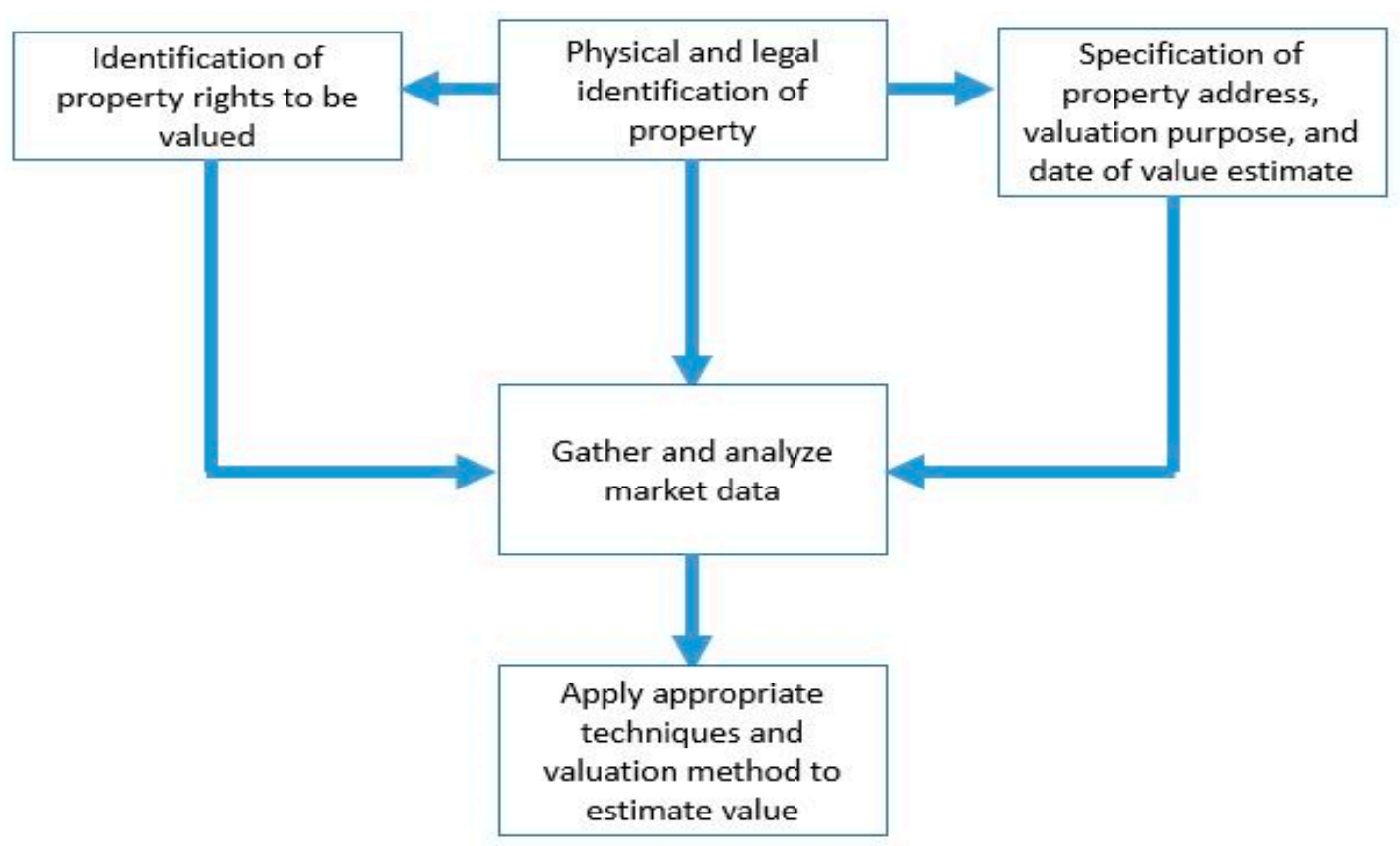

Figure 4. Land valuation process. Authors' construct.

Land taxation, currently referred to as property taxation or rating in Ghana, is one of the oldest tax forms [61]. In Ghana, this tax is paid with respect to a developed land or an immovable property [62]. Property tax differs amongst countries as it is paid in respect of; the land only in Kenya and Jamaica, buildings and improvements on land in Kosovo, and Tanzania, or to both in Canada, Germany, Japan, some parts of Australia, the United Kingdom, Indonesia, Thailand, Guinea, and Tunisia [62]. In Ghana, District Assemblies are the governmental institutions charged with the responsibility of preparing and levying property tax or rates in their areas of jurisdiction as per Section 144 of Act 936 [63]. Property taxation in Ghana is based on the replacement cost method/contractor's cost method of valuation. The tax is the replacement cost of the property after depreciation is deducted, and this should not exceed $50 \%$ of the replacement cost of an owner occupier's premises and must not be less than $75 \%$ in other cases [63]. The property taxation process in Ghana is illustrated in Figure 5 below. 


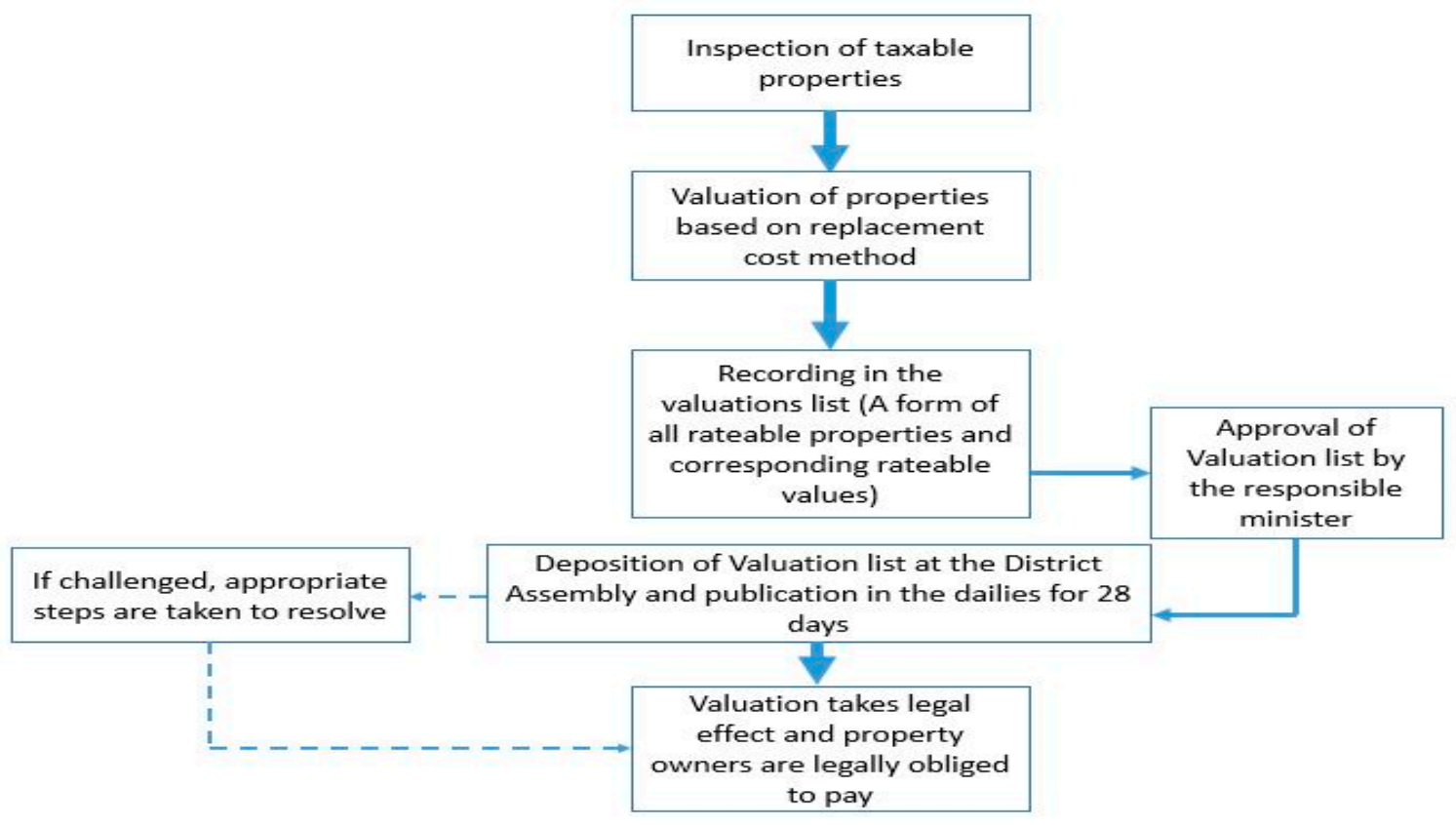

Figure 5. Property taxation process. Based on $[62,63]$.

\subsubsection{Land Use Planning and Land Development Processes}

Land use planning and land development are closely linked and as such discussed together [30]. Land use planning is concerned with the planning and control of the use of land and natural resources, while the land development process is concerned with the implementation of development plans. Land development involves the building of new physical infrastructures and the implementation of construction planning and a change of land use through planning permissions and the granting of permits [55]. The designation of different land areas for different use types such as residential, commercial, recreational, and markets, and the actual carrying out of these plans based on the adoption of planning policies and land use regulations for a country, covering the national, regional to the local levels [55]. Land use planning and development in Ghana is concerned with balancing competing land uses for sustainable human settlement development [64]. The main legislation regulating land use planning in Ghana is the Town and Country Planning Ordinance, 1945 (CAP 84) [31]. Other legislations that border on physical planning in general include, National Development Planning System's Act, 1994 (Act 479), the Local Government Act, 2016 (ACT 936) and the National Building Regulations, 1996 (LI 1630) [65,66]. Land use planning in Ghana covers spatial, land use, and human settlement planning [67]. In Ghana, land use planning must ideally be based on decentralization and participatory principles $[51,66,68]$. Land use and development plans are prepared at the district level, forwarded and harmonized with those prepared at the regional level, and the two forwarded to the national level to the National Development Planning Commission (NDPC), where they are evaluated, and approval can be given for implementation [51,66,68].

The land use planning and development process in Ghana starts with the survey and definition of an area base map. This stage entails the collection, analysis, interpretation, and presentation, in a readily understood form, of all the data that are likely to influence the proposals which will be included in the land use plan. Here, planners with the help of local community people study the area to become conversant with all the characteristics which will help in defining the broad land use categories; residential, commercial among others [67]. Data are gathered through different survey types including a physical survey for data relating to topography, landscape, agricultural lands, and sometimes the geology of the area, a social survey gathers data on the population and its characteristics like the size, composition, structure, and housing, traffic transportation survey data includes the occupation, place of work, or school, origin and destination of work, rail and road networks, and parking facilities. 
The survey stage is then followed by the planning stage. In planning, the goals and terms of reference are established as the first stage. At this stage, the planning area is defined, and all the involved people contacted. Some basic data of the area are gathered, and followed by a preliminary identification of problems and opportunities, as well as constraints to implementing improvement. The planning period is then set. The second stage is the organization of the work. This involves listing the planning tasks and activities and identifying the people or organizations responsible for these tasks or for contributing to them. Then, the needed resources are set out, and the work plan for the project as a whole is drawn up. Administrative matters and logistics are then arranged and provision is made for transport and other equipment. The third stage is a problem analysis which analyzes the causes of the problem in relation to the data already collected on the existing situation; population, land use, land resources, income, and occupation, among others. Constraints to change are then identified. The fourth stage involves identifying opportunities to change by first identifying and drafting a range of land use types that might help to achieve the goals of the plan. Generate a range of options for solving each problem in terms of opportunities; economic measures, land resources, government actions, the people, improved technology, and in terms of land use strategies; no change, maximum production, maximum conservation, etc. The fifth stage is the land suitability evaluation. At this stage, for each promising land use type, establishing the land requirements and matching these with the properties of the land to establish physical land suitability. The sixth stage comprises the appraisal of alternatives through social and economic analysis. That is, for each physically suitable combination of land use, the environmental, economic and social impacts, of the favorable and unfavorable, and of alternative courses of action, are assessed. Therefore, there should be an environmental impact assessment, financial and economic analysis, social impact assessment, and strategic planning. The seventh stage is the choosing of best options. Firstly, public and executive discussions are held on the viable options and their consequences. The comments from these discussions are then assembled and reviewed, and based on these, the necessary changes are made to the options. A decision is then made on which changes in land use should be made or worked towards. The last stage of planning is the preparation of a land use plan through zoning. This starts with the allocation or recommendation of the selected land uses for the chosen areas of land, followed by preparing the maps, the basic or master land use plan and supporting maps. After this, plans for how the selected improvements should be brought about, and how the plan is to be put into practice are made through an appropriate land management approach. A policy to guide the implementation is then drawn up, the budget is prepared and any necessary legislation drafted. It is important to mention the need for the involvement of decision-makers, sectoral agencies, and land users. The last stage of land use planning and development process is implementation. At this stage, the plan is put into action which is the responsibility of both the implementation agencies (mainly the town and country planning department) and the planning teams. During the implementation, there is the monitoring and revision of the plan in light of the goals defined at the initial stage as well as in light of the experiences that occur.

The land use planning and development process is summarized in Figure 6 below.

The next section discusses the transparency issues inherent to these different land administration processes and the role of blockchain technology to potentially resolve these. 


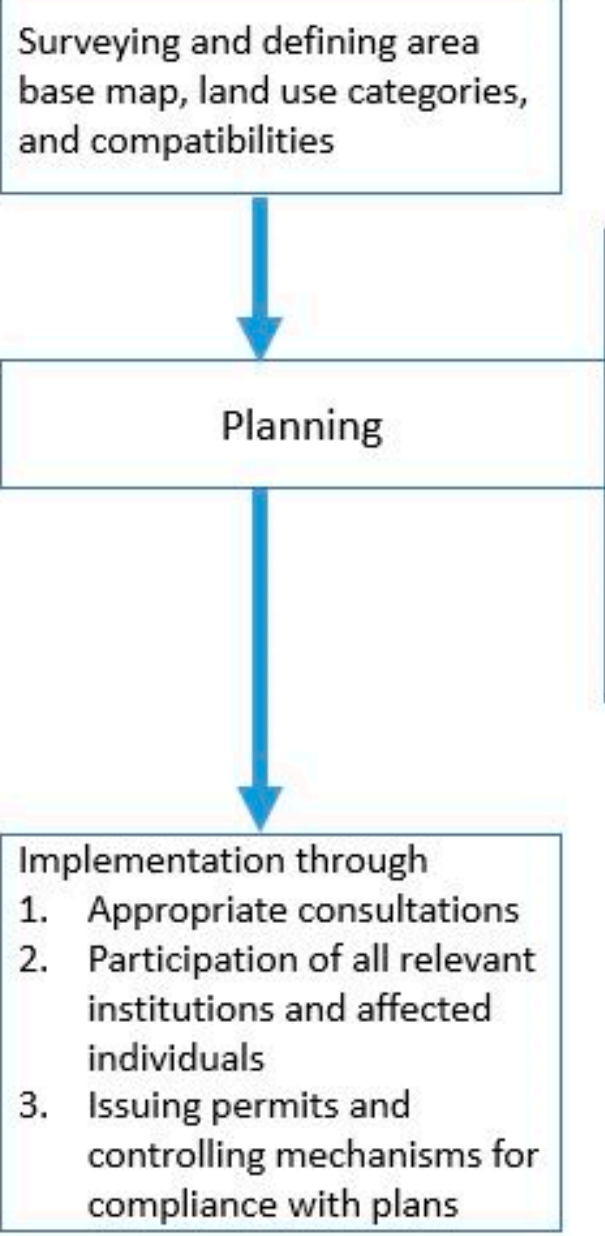

1. Establishing goals and terms of reference

2. Organizing the work

3. Analyzing problems

4. Identifying opportunities for change

5. Land suitability evaluation

6. Appraisal of alternatives through environmental, social, and economic analysis

7. Choosing best options

8. Preparing the land use plan through zoning

Figure 6. Land use planning and development process. Authors' construct.

\section{Discussion}

Transparency Issues of Land Administration Processes in Ghana and the Role of Blockchain Technology

Figure 7 below shows a four-dimensional framework for the transparency of land administration. The framework and its subsequent analysis and synthesis comprehensively capture and identify the transparency issues in the land administration processes, as highlighted under the findings, and highpoint how these processes can be made transparent, and the role of blockchain towards this. The transparency of land administration processes involves carrying out and sharing up-to-date information on ownership, value, and the use of land and all of its associated resources among related institutions, right holders and other stakeholders, including third parties, as well as, acting on the information in an open manner $[30,55]$. Transparency allows citizens unbridled access to land data, activities, organizations and professionals in an open and participatory manner in taking and implementing land decisions [4]. The availability/sharing of and accessibility to relevant land data, openness, and participatory processes in land administration thus underline the transparency of land administration in the context of this paper. Transparency issues appear akin across the different land administrations processes. For this reason, the discussion of blockchain's role towards addressing these issues has been integrated so as to give a better correlation and appreciation of the issues across the different land administration processes. 


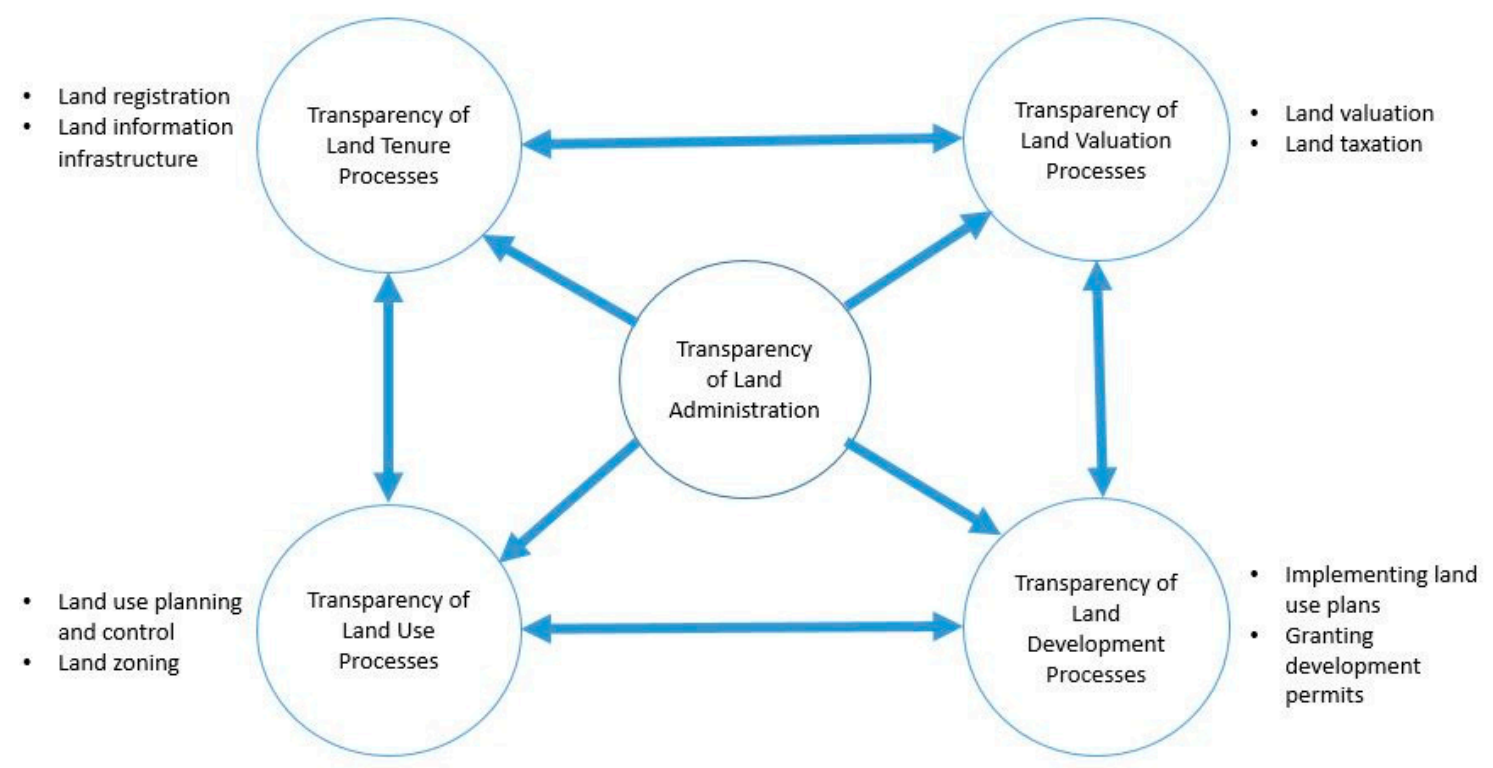

Figure 7. Transparency of the land administration framework. Source: authors' construct based on $[30,55]$.

Taking the inventory of tenure by land registration significantly contributes to the openness, availability of information, and transparency of who owns and uses land [69]. Ensuring transparency thus depends on the establishment of land registers where they do not exist yet, making records accessible, securing transaction procedures, and documenting processed information [30]. When only regarding the legal context related to land registration in Ghana, one will expect openness and transparency in the system as outlined in our findings. However, [61] notes that in practice, the land registration procedure is cumbersome and fraught with lots of informal dealings, secrecy, bribery and corruption. In a 2016 survey, $69 \%$ and $9 \%$ of citizens that had received their registration certificates between 3-5 months and 6-8 months, respectively, indicated that they had paid bribes to middlemen or staff of the national land commission (NLC) to facilitate the process, whereas, those that had refused to pay bribes had their documents neglected, and prolonged to between 6 and 12 months to receive their land certificates [58]. This malicious delay due to the non-payment of the bribe is attributed to the lack of openness and transparency in the system which inhibits clients' ability to know the status of their registration documents in order to tell if documents are being unnecessarily delayed. The author [70] was correct to note that there is information asymmetry in Ghana's land sector, and that land information is monopolized by public land institutions. There is a lack of transparency [71] as well as information imbalance among land stakeholders, which greatly debilitates obtaining credible information due to the failure to divulge information between stakeholders, particularly to clients. This situation refutes the openness, availability and accessibility to information, and the participatory principles of land administration transparency.

On a technical level, the computerization of land registration processes can help to enhance transparency by giving citizens direct access to relevant data and also allow them to monitor process' progress [69]. Technically, introducing blockchain in an already established registration processes is feasible [2,29,44,46]. Ethereum Blockchain's smart contract for example is possible in Ghana's case [71]. Smart contract applications allow for predefined rules and requirements of the registration processes in order to be carried out successfully when these rules and requirements are met [16]. The design architecture of a public permissionless blockchain allows all transaction stakeholders, a free accessibility to information about the transaction and its processes by integrating all of them. In this way, the ability of documents to move through the stages of registration is independent of any single NLC officer or middleman, but subject to meeting all predefined conditions of the process, which every stakeholder can monitor equally. The whole registration process, from lodgment stage, through to the issuing and 
collection of the land certificate, thus becomes controlled by all stakeholders in the transaction due to their integration. This will not only expedite the registration process but also ensure the trust and credibility of land registration documents and processes. It is important to mention that, the manual stages of physical inspection, as well as survey and mapping services will still remain. However, these physical stages can now be brought under the complete monitoring of all concerned stakeholders, since everyone is aware of every stage of the registration. Stakeholders can therefore monitor these physical stages when they are due. This will help stakeholders to be able to validate the outputs of these physical processes as the accurate representation of the ground realities or not. Thus, in lieu of the transparency of land administration processes, a blockchain can boost land registration process by enhancing;

- Openness: through the decentralized broadcasting of transactions to all the integrated stakeholders, every decision or action can be known to all and no action can be hidden. Thus, although the different stages of the registration process involve different stakeholders, every stakeholder is aware of each stage, as well as, what, how, and when work is done on the transaction which allows for openness.

- Availability and access to land information: information imbalance obstructs accessibility to credible land data which breeds ignorance and permits fraudulent deals as some stakeholders become oblivious of other happenings in the transaction. The decentralized broadcasting of transactions and all associated information across the stakeholders, coupled with the verification and validation, as well as the hashing of new transaction blocks to historical blocks allows for easy accessibility to all relevant information (both current and historical) on land ownership, parcel, and rights, by all stakeholders at all times. This will help eliminate information asymmetry and its associated challenges of bribery and corruption.

- Participatory processes: the verification and validation through the consensus mechanism foster maximum participation in the entire registration processes from all stakeholders, since this allows the majority stakeholders to be part of transactions' decision making every time. The consensus mechanism takes place at every stage of the registration process until it is completed. Moreover, the broadcasting of process stages to all stakeholders automatically induces participation in the processes either actively or inactively. This is because everyone is aware of every happening and can give their contributions accordingly as and when necessary. That is, stakeholders are always privy to and aware of all the happenings and processes. This makes every stakeholder part of the transaction and registration processes in the participatory sense.

Regarding land information infrastructure, this typically relies on accurate and accessible cadastral and topographic datasets [55]. In Ghana, however, land information at the disposal of the different divisions of NLC is always not up-to-date because there is a lack of synchronization within the information infrastructure [71]. This challenge sometimes allows unauthorized tampering with land documents and data by some unscrupulous officials [71], across all divisions and in all the land processes. This is made possible because of the manual land administration system. This challenge can however be eliminated through the digitization and application of blockchain across the different divisions [2]. Every change on blockchain updates automatically without human efforts. This will thus provide up-to-date data at every point in time across all the divisions of the NLC and in all their processes. In this way, in addition to facilitating the data accessibility, openness and participatory processes, the blockchain will ensure up-to-date land data all the time to enhance all the land administration processes and decisions $[6,55]$. These potentials of blockchain if combined with the publication in the dailies stage of registration process and land taxation processes, will boost openness, transparency and participation for all citizens for transparency in the system.

Land valuation must represent an unbiased estimate, a learned opinion and a supported value estimate. Where there is no openness in the valuation processes, biases cannot be identified. Where there are difficulties in accessing market data on comparable properties, valuation will not reflect the 
reasonable market value. Moreover, where there is no participation in the valuation process from involved stakeholders, it will not be possible to achieve an 'arm's length transaction' since parties will have limited idea of the actual market situation. Again, maximum participation helps to avoid value conjecture on the part of some valuers who may skip some appropriate valuation steps like the physical inspection of the property and its comparables, due to the laborious and tedious nature of these valuation steps. In [30], the authors note that land value data is useful to achieve the arm's length transaction as it gives data for comparison purposes. A major challenge of valuation process in Ghana is the access to readily available and up-to-date market data on comparable properties, either from property owners or from the land institutions. This is due to the secrecy amongst land stakeholders, lack of transparency, and also information imbalance as identified in [70-72]. The same challenges that lead to land registration challenges and lengthy processing time. These greatly affect the valuation processes and the possibility of valuation results to reflect the current market situation and factors. On this basis, if registered properties and registration processes are carried out on blockchain as discussed already, the valuation processes can be linked to and carried out on this blockchain system. In so doing, since all registered properties and their data are readily available, it will facilitate access to the market data on comparables, particularly of registered properties. The openness of the system will also permit all stakeholder awareness of the valuation process to achieve the arm's length transaction [30], and a truly reflexive market value which is based on the prevailing market situations and factors. The choice of valuation method and its appropriateness can also be evaluated by stakeholders, particularly given that comparables with the same basis and purpose of valuation can easily be found from registered properties via the blockchain system. Therefore, with the secure, immutable, time-stamped, and up-to-date characteristics of the blockchain-based land administration system [24], accessibility to comparables for valuation is made easier and faster, as well as is open to the knowledge of all stakeholders. Thus, the valuation process from, identifying property owners, and comparables, through choosing a valuation technique, to actual valuation, can then be carried out via the blockchain system. This can help to eliminate value conjecture by some valuers due to the difficult accessibility to market data on comparables, as well as ignorance on the part of other stakeholders of the valuation processes. This can also address petty mistakes like wrong addresses, incorrect party details, valuation dates, as well as the exact rights to properties since other stakeholders can identify and rectify these through verification and validation.

The valuation process is similar to the taxation process. The difference is that the valuation list for taxation is, however, published in the dailies for 28 days before they can become legally binding, In property taxation, a major challenge in making property tax administration effective in Ghana is the difficulty in connecting properties to their locations, and also where transparency is lacking in the system $[62,72,73]$. To boost effectiveness therefore, there must be openness, as well as availability of and accessibility to property location and other information. Since the taxation process is just like the valuation processes, this can also be carried out using blockchain. Blockchain will make the identification of registered property easier for taxation as they are readily listed in the system. In this way, the process involved in levying property taxes will become open to stakeholders and give easy access to information queries and clarifications, to make the system open and participatory for transparency. Moreover, taxation records can be kept securely in this system to eliminate inherent illegalities as well as to ensure that all taxes are channeled into the right government coffers since any diversion of taxes will be known on the blockchain system.

In view of the transparency challenges of the land administration processes in the foregoing discussions, the current Ghanaian system of land use planning and development has been criticized, despite the requirement for all developments to proceed with issuing development permits [72]. The argument underlying this critique is that the system does not promote compliance $[65,73]$. This is a problem not only in Ghana but across the sub-Saharan Africa region. The authors in [74] noted that between $50 \%$ and $75 \%$ of all the new houses in the region's cities were developed on lands delivered through processes that do not comply with all the legal requirements. In Ghana, [74] again noted 
that $31 \%$ of property owner respondents had building permits while $69 \%$ had no building permits, and neither were they in the process of or taking steps with the aim of acquiring one. Of the $31 \%$ respondents that had building permits, only $23.3 \%$ had acquired permits prior to starting construction, while $76.7 \%$ did so subsequently to their building commencement [74]. The educated and formal sector employees who were aware of land use planning and development were the most that had building permits and 'there is the likelihood for such people to have connections and influence to aid their acquisition of building permit' [74] (p. 21). Without such connections and influence, a person is likely to face challenges like unnecessary delays, and the paying of illegal monies, just as was seen under the land registration process, before they can receive permits to commence developments [74]. There is therefore negative trust perceptions for land use planning and development officials, and the system [75]. In [66], the authors identified a lack of involvement and or participation and better knowledge of land use planning amongst the majority of citizens, and recommended 'the need for planning authorities to adopt participatory land use planning together with customary landholders, and educating them on the essence of comprehensive land use planning approaches' [66] (p. 4), [42]. These problems account for the low compliance with land use planning and development regulations, leading to a high rate of unauthorized developments. Land use planning and development processes need to be as open and as transparent as possible to allow for equal awareness, better knowledge, and accessibility to the system for all citizens. Adopting participatory approaches to planning by involving citizens, particularly those affected by the planning scheme, is a means to create awareness and to boost trust for the system [76]. Blockchain technology which integrates all stakeholders in a transaction and decision-making processes can facilitate the participatory planning approaches. A permissionless public blockchain (this allows all stakeholders to have open access, join, and partake in decisions without restrictions) is useful in this sense [45]. Citizens have to sign up to this permissionless blockchain via their computers or other supportive devices. They will then be assigned confidential private keys with which to sign into the system every time to be able to initiate a request or partake in discussions or transactions as seen in Figure 1 under findings. No external permission is necessary. Therefore, stakeholders can login to see all land use planning and development discussions and actions, follow it and contribute to it where necessary. To achieve this will, however, require intensive public education and awareness creation for the majority of citizens to know the use and be able to partake in the system. If this is done, it can improve more citizenry participation in processes and decisions on land use planning and development. The improved accessibility and participatory processes can consequently enhance openness, transparency, and increased trust among stakeholders. This is because it is impossible to hide decisions and processes from any stakeholder. Digitizing land use planning and development processes and data on blockchain system will therefore integrate all stakeholders. In this way, stakeholders can monitor areas for which land use permits have been granted and areas for which they have not been granted since these data will reflect on the blockchain system, and be known to all stakeholders. Citizens can then act as watchdogs, and to report on any developments that commence without the right approval. This can help to end the non-compliance to land use planning and development schemes, as well as the indiscriminate and unauthorized developments.

Improved participation through the use of a blockchain system for land transaction helps citizens to have control and security over the data. This enhances the take-up and trust in government institutions and processes to support sustainable economic growth as identified in the implementation of Georgia's blockchain land registration project [76]. A counter argument that such an improved open accessibility and participatory process can lead to opportunistic behaviors and misinformation can be made. However, blockchain's design architecture provides for systematic review and checks for all decisions and information. This is done by the majority stakeholders through the verification and validation (consensus mechanism) of data based on the good knowledge of actual grounds work, sources, history, and credibility of the stakeholder that is making or giving such decisions and data before they are accepted as true and authentic [23]. Based on the blockchain's elements of distributive decentralization (which integrates all land stakeholders), the consensus mechanism, hashing of records, 
immutability, and synchronization of data, land administration processes can be carried out in a way that is open to all stakeholders to ensure transparency, enhance trust amongst stakeholders, as well as achieve up-to-date data at all times for land decisions. This can be achieved by adopting a single permissionless public blockchain system for the different land administration divisions and their processes. The manual land administration functions like surveying and physical inspections will still be manual but can now be done with all other stakeholders being aware. This is because, blockchain is a decentralized technology and permits everyone on the system to know and be aware when each of the land transaction stages is due. This allows stakeholders to be able to follow, and to keep an oversight check on these processes to confirm accuracy through validation. Applying blockchain across all processes of land administration in such a simultaneous approach has synergistic effects of real-time data update, accessibility, and openness across them. This makes it easier for each stakeholder to keep-up, and to participate in decisions and transactions. It also ensures easy access to readily available land data for all interested stakeholders.

\section{Conclusions}

This paper aimed to identify the essential elements and relations between the blockchain technology and transparency of land administration in the existing literature, and to assess the potential of blockchain to improve the transparency of land administration processes-based on the context from Ghana. These aims were achieved through a comprehensive review of all the land administration processes in Ghana, the inherent transparency issues in them, and the possibility of blockchain to support and enhance transparency in these processes simultaneously. The paper argued and demonstrated that the completeness of land administration transparency is when transparency is achieved across all land administration processes, and stakeholders simultaneously. A single permissionless public blockchain can help achieve this. However, there is the need for the different land divisions to establish standardization in the land administration processes prior to the blockchain's application in such a compressive approach. This is because, where there is no such standardization, there is a high possibility of inconsistencies and irregularities in the processes across the different divisions which can affect the efficient working of the blockchain system across all the divisions.

This study is relevant for all land stakeholders, as it provides a better understanding, and an interpretive approach to the social and political realities of land administration in Ghana. It has also extended the discourse on the topic and offers a quick and easy reference guide for scholars, practitioners, and policy makers as hitherto, land administration processes and transparency issues in Ghana have been discussed individually, in piecemeal and scattered across different works, which hindered a better appreciation of the topic due to the polarization and different epistemological views $[35,49,51-53,62,65]$.

As part of the policy implications for blockchain adoption, there should be a review of all paper-based land transactions for errors and corrections, and a comprehensive digitization of land administration transactions and processes in the country, in addition to the public-private partnership in the blockchain-based land administration process. Again, an intensive public education, particularly for land stakeholders, is necessary to understand the blockchain system before implementation can begin. Finally, as seen in the findings, blockchains will affect the institutional relations and shared authorities between all stakeholders which include government agencies, local chiefs and individual landowners. This is because, land decisions and associated activities are no longer dependent on a single party, but are going to be a shared effort. It is therefore important that this new decentralized and shared authority be deliberated, and negotiated to reach a consensus, particularly with the chiefs. This is because chiefs own $80 \%$ of land in Ghana and hence, there is a need for their consent and cooperation if blockchain implementation can be successful. As a consequence to establishing this, blockchain can fundamentally change the transparency variations in land administration to be more equal and homogeneous, regardless of the type of land. 
The nascent nature of the topic area, and limited conceptualizations, hindered the ability to explore more options and in further detail, the blockchain architecture types that can possibly support such a comprehensive transparency of land administration as presented in this study. We therefore recommend that future research focuses on exploring this area. Moreover, since this study focused mainly on statutory land administration processes, future research works should consider the topic from the customary land administration perspective especially, given that customary lands cover $80 \%$ of land in Ghana, are governed by different indigenous customary laws, and are based on a low level of technological how-how. Finally, future researcher works, and potential institutions for blockchain adoption, should be aware of and take into consideration the technology's flaws in terms of limited storage capacity, the limitations to its scalability and speed, as well as the huge electricity consumption for its operation.

Author Contributions: Conceptualization, methodology, investigation, resources, formal analysis, validation, data curation, writing — original draft, writing — review and editing: P.D.A. and W.T.d.V.; Supervision: W.T.d.V. All authors have read and agreed to the published version of the manuscript.

Funding: This research received no external funding.

Acknowledgments: This study was carried out within the timeframe of a Ph.D. research program at the Technische Universität München (TUM), the Chair of Land Management and Land Tenure. The Ph.D. program was funded by the Katholischer Akademischer Auslander-Dienst (KAAD). We appreciate the financial support of the studies. This research received no external funding. Appreciation also goes out to the anonymous readers that read through and offered constructive comments to help improve the initial draft, as well as to the main reviewers of the paper. We say a big thank you for your valuable comments for the paper's improvement.

Conflicts of Interest: The authors declare no conflict of interest.

\section{References}

1. Vos, J.; Lemmen, C.; Beentjes, B. Blockchain-Based Land Administration Feasible, Illusory or a Panacea? In Proceedings of the Responsible Land Governance: Towards an Evidence Based Approach, Washington, DC, USA, 20-24 March 2017. [CrossRef]

2. Lemmen, C.; Vos, J.; Beentjes, B. Ongoing Development of Land Administration Standards: Blockchain in Transaction Management. Eur. Prop. Law J. 2017, 4, 478-502. [CrossRef]

3. Dawidowicz, A.; Źróbek, R. Land Administration System for Sustainable Development-Case Study of Poland. Real Estate Manag. Valuat. 2017, 4, 112-122. [CrossRef]

4. Bagdai, N.; van der Molen, P.; Tuladhar, A. Does uncertainty exist where transparency is missing? Land privatisation in Mongolia. Land Use Policy 2012, 4, 798-804. [CrossRef]

5. Williamson, I.P.; Grant, D.M. United Nations-FIG Bathurst Declaration on Land Administration for Sustainable Development: Development and Impact. In Proceedings of the XXII FIG International Congress, Washington, DC, USA, 19-26 April 2002.

6. Enemark, S. Building land information policies. In Proceedings of the Special Forum on Building Land Information Policies in the Americas, Aguascalientes, Mexico, 26 October 2004; Volume 26, p. 2004.

7. Locke, A.; Henley, G. The Possible Shape of a Land Transparency Initiative: Lessons from Other Transparency Initiatives. 2013. Available online: http://search.ebscohost.com/login.aspx?direct=true\&db=lah\&AN= 20133405582\&site=ehost-live\%5Cnhttp://www.odi.org.uk/sites/odi.org.uk/files/odi-assets/publicationsopinion-files/8599.pdf\%5Cnemail:a.locke@odi.org.uk (accessed on 1 February 2020).

8. UN-Habitat. Tenure Responsive Land Use Planning: A Guide for Country Level Implementation. 2016. Available online: www.unhabitat.org (accessed on 18 April 2020).

9. Bell, K.C.; Bell, K.C. Good Governance in Land Administration; World Bank: Washington, DC, USA, 2007.

10. Phuong, T.H. Enhancing Transparency in Land Transaction Process by Reference Architecture for Workflow Management System. In Proceedings of the PACIS, Ho Chi Minh City, Vietnam, 11-15 July 2012; p. 69.

11. Anand, A.; McKibbin, M.; Pichel, F. Colored Coins: Bitcoin, Blockchain, and Land Administration. In Annual World Bank Conference on Land and Poverty. 2015. Available online: https://www.ubitquity.io/home/ resources/worldbank_land_paper_ubitquity_march_2016.pdf (accessed on 8 January 2020). 
12. Bagdai, N.; van der Veen, A.; van der Molen, I.P.; Tuladhar, A. Transparency as a Solution for Uncertainty in Land Privatization-A Pilot Study for Mongolia. In Proceedings of the Surveyors Key Role in Accelerated Development, Eilat, Israel, 3-8 May 2009.

13. Jaitner, A.; Caldeira, R.; Koynova, S. Transparency International-Land Corruption in Africa-Finding Evidence, Triggering Change. In Proceedings of the Annual World Bank Conference on Land and Poverty, Washington, DC, USA, 20 March 2017.

14. Spielman, A. Blockchain: Digitally Rebuilding the Real Estate Industry. Ph.D. Thesis, Massachusetts Institute of Technology, Cambridge, MA, USA, 2016.

15. Lemieux, V.L. Evaluating the Use of Blockchain in Land Transactions: An Archival Science Perspective. Eur. Prop. Law J. 2017, 4, 392-440. [CrossRef]

16. Rizal Batubara, F.; Ubacht, J.; Janssen, M. Unraveling Transparency and Accountability in Blockchain. In Proceedings of the 20th Annual International Conference on Digital Government Research, Dubai, UAE, 18-20 June 2019; pp. 204-213. [CrossRef]

17. Müller, H.; Seifert, M. Blockchain, a Feasible Technology for Land Administration? In Proceedings of the FIG Working Week, Hanoi, Vietnam, 22-24 April 2019.

18. Singh, H.; Gupta, H.; Singh, A.; Litoria, P.K. Applications of Blockchain for Land Record Management. In Proceedings of the National Conference on Role of Geospatial Technologies to Bridge the Rural and Uraban Divide, Ludhiana, India, 22-23 February 2018.

19. Eder, G. Digital Transformation: Blockchain and Land Titles. In Proceedings of the OECD Global Anti-Corruption \& Integrity Forum, Paris, France, 20-21 March 2019.

20. Shang, Q.; Price, A. A Blockchain-Based Land Titling Project in the Republic of Georgia: Rebuilding Public Trust and Lessons for Future Pilot Projects. Innov. Technol. Gov. Glob. 2019, 4, 72-78. [CrossRef]

21. Bal, M. Securing Property Rights in India Through Distributed Ledger Technology; Observer Research Foundation: New Delhi, India, 2017.

22. Benbunan-Fich, R.; Castellanos, A. Digitalization of land records: From paper to blockchain. In Proceedings of the International Conference on Information Systems 2018, ICIS 2018, San Francisco, CA, USA, 13-16 December 2018.

23. Thakur, V.; Doja, M.N.; Dwivedi, Y.K.; Ahmad, T.; Khadanga, G. Land records on blockchain for implementation of land titling in India. Int. J. Inf. Manag. 2020, 4, 101940. [CrossRef]

24. Lazuashvili, N.; Norta, A.; Draheim, D. Integration of Blockchain Technology into a Land Registration System for Immutable Traceability: A Casestudy of Georgia. In Proceedings of the International Conference on Business Process Management, Vienna, Austria, 1-6 September 2019; Volume 361, pp. 219-233. [CrossRef]

25. Krishnapriya, S.; Sarath, G. Securing Land Registration using using Blockchain Blockchain. Procedia Comput. Sci. 2020, 4, 1708-1715. [CrossRef]

26. Vos, J. Blockchain-based land registry: Panacea illusion or something in between? In Proceedings of the IPRA/CINDER Congress, Dubai, UAE, 22-24 February 2016.

27. Kempe, M. The Land Registry in the Blockchain-Testbed; A development project with Lantmäteriet, Landshypotek Bank, SBAB, Telia Company, ChromaWay and Kairos Future. European Urology Supplements; Kairos Future: Stockholm, Sweden, 2017. [CrossRef]

28. Peiró, N.N.; García, E.J.M. Blockchain and Land Registration Systems. Eur. Prop. Law J. 2017, 4, $296-320$. [CrossRef]

29. Yapicioglu, B.; Leshinsky, R. Blockchain as a tool for land rights: Ownership of land in Cyprus. J. Prop. Plan. Environ. Law 2020. [CrossRef]

30. Yildiz, U.; Zevenbergen, J.; Todorovski, D. Exploring the Relation between Transparency of Land Administration and Land Markets: Case Study of Turkey. In Proceedings of the FIG Working Week 2020 Smart Surveyors for Land and Water Management, Amsterdam, The Netherland, 10-14 May 2020.

31. Torraco, R.J. Writing Integrative Literature Reviews: Using the Past and Present to Explore the Future. Hum. Resour. Dev. Rev. 2016, 15, 404-428. [CrossRef]

32. Snyder, H. Literature review as a research methodology: An overview and guidelines. J. Bus. Res. 2019, 4, 333-339. [CrossRef]

33. Ntihinyurwa, P.D.; de Vries, W.T. Farmland fragmentation concourse: Analysis of scenarios and research gaps. Land Use Policy 2020, 4, 104936. [CrossRef] 
34. Torraco, R.J. Writing Integrative Literature Reviews: Guidelines and Examples. Hum. Resour. Dev. Rev. 2005, 4, 356-367. [CrossRef]

35. Obeng-odoom, F. Urban property taxation, revenue generation and redistribution in a frontier oil city. Cities 2014, 4, 58-64. [CrossRef]

36. Webster, J.; Watson, R.T. Analyzing the Past to Prepare for the Future: Writing a Literature Review. MIS Q. 2002, 26, xiii-xxiii.

37. Gale, N.K.; Heath, G.; Cameron, E.; Rashid, S.; Redwood, S. Using the framework method for the analysis of qualitative data in multi-disciplinary health research. BMC Med. Res. Methodol. 2013, 4, 1-8. [CrossRef]

38. Levack, W.M. The role of qualitative metasynthesis in evidence-based physical therapy. Phys. Ther. Rev. 2012, 4, 390-397. [CrossRef]

39. Karamitsos, I.; Papadaki, M.; Al Barghuthi, N.B. Design of the Blockchain Smart Contract: A Use Case for Real Estate. J. Inf. Secur. 2018, 4, 177-190. [CrossRef]

40. Natarajan, H.; Krause, S.K.; Gradstein, H.L. Distributed Ledger Technology (DLT) and Blockchain; FinTech note, no. 1; World Bank Group: Washington, DC, USA, 2019.

41. Themistocleous, M. Blockchain Technology and Land Registry. Cyprus Rev. 2018, 4, 195-202.

42. Shuaib, M.; Daud, S.M.; Alam, S.; Khan, W.Z. Blockchain-based framework for secure and reliable land registry system. Telkomnika 2020, 4, 2560-2571. [CrossRef]

43. Oberdorf, V. Building Blocks for Land Administration: The Potential Impact of Blockchain-Based Land Administration Platforms in Ghana. Master's Thesis, Utrecht University, Utrecht, The Netherlands, 2017.

44. Kaczorowska, M. Blockchain-based land registration: Possibilities and challenges. Masaryk Univ. J. Law Technol. 2019, 4, 339-360. [CrossRef]

45. Makala, B.; Anand, A. Blockchain and Land Administration. J. Dev. Stud. 2018, 4, 1-34.

46. Ølnes, S.; Ubacht, J.; Janssen, M. Blockchain in government: Benefits and implications of distributed ledger technology for information sharing. Gov. Inf. Q. 2017, 4, 355-364. [CrossRef]

47. Petkova, P.; Jekov, B. Blockchain in e-Governance. In Selected and Extended Papers from X-th International Scientific Conference 'E-Governance and e-Communication'; SSRN: Rochester, NY, USA, 2018; p. 149.

48. Shapiro, E.; Mackmin, D.; Sams, G. Modern Methods of Valuation; Taylor \& Francis: Boca Raton, FL, USA, 2012.

49. Agyemang, F.S.K.; Morrison, N. Recognising the barriers to securing affordable housing through the land use planning system in Sub-Saharan Africa: A perspective from Ghana. Urban Stud. 2017, 4, 2640-2659. [CrossRef]

50. Stefanović, Đ.M.; Pržulj, D.; Ristic, S.; Stefanović, D. Blockchain and Land Administration: Possible applications and limitations. In Proceedings of the International Scientific Conference on Contemporary Issues in Economics Business and Management, Kragujevac, Serbia, 9-10 November 2018.

51. Fuseini, I.; Kemp, J. A review of spatial planning in Ghana's socio-economic development trajectory: A sustainable development perspective. Land Use Policy 2015, 4, 309-320. [CrossRef]

52. Kuusaana, E.D. Property rating potentials and hurdles: What can be done to boost property rating in Ghana? Commonw. J. Local Gov. 2015, 204-223. [CrossRef]

53. Kleemann, J.; Inkoom, J.N.; Thiel, M.; Shankar, S.; Lautenbach, S.; Fürst, C. Peri-urban land use pattern and its relation to land use planning in Ghana, West Africa. Landsc. Urban Plan. 2017, 4, 280-294. [CrossRef]

54. Stahl, J.; Sikor, T.; Dorondel, S. Transparency in Albanian and Romanian land administration. Paper Forthcoming in the Next Issue of Cahiers Options Méditerranéennes entitled "La Question Foncière Dans les Balkans". 2008. Available online: http://www.landcoalition.org/pdf/07_paper_transparency_land.pdf (accessed on 14 August 2020).

55. Enemark, S. Understanding the land management paradigm. In Proceedings of the FIG Commission 7, Symposium on Innovative Technologies for Land Administration, Madison, WI, USA, 18-25 June 2005; pp. 19-25.

56. Zevenbergen, J. A Systems Approach to Land Registration and Cadastre. Nord. J. Surv. Real Estate Res. 2004, 1. Available online: https://journal.fi/njs/article/view/41503 (accessed on 18 August 2020).

57. Sittie, R. Land title registration. The Ghanaian experience. In Proceedings of the 23rd FIG Congress, Munich, Germany, Munich, Germany, 8-13 October 2006.

58. Ehwi, R.J.; Asante, L.A. Ex-Post Analysis of Land Title Registration in Ghana since 2008 Merger: Accra Lands Commission in Perspective. Sage Open 2016, 4, 2158244016643351. [CrossRef] 
59. Mintah, K.; Baako, K.T.; Kavaarpuo, G.; Otchere, G.K. Skin lands in Ghana and application of blockchain technology for acquisition and title registration. J. Prop. Plan. Environ. Law 2020. [CrossRef]

60. Asiama, K.O.; Bennett, R.; Zevenbergen, J.; Asiama, S.O. Land valuation in support of responsible land consolidation on Ghana's rural customary lands. Surv. Rev. 2018, 4, 288-300. [CrossRef]

61. Kuusaana, E.D. Property taxation and its revenue utilisation for urban infrastructure and services in Ghana: Evidence from Sekondi-Takoradi metropolis. Prop. Manag. 2016, 4, 297-315. [CrossRef]

62. Petio, M.K. Role of the Land Valuation Division in Property Rating by District Assemblies in Ghana's Upper East Region. Commonw. J. Local Gov. 2013, 4, 69-89. [CrossRef]

63. GOG. Local Government Act; GOG: Warsaw, Poland, 2016.

64. Yeboah, E.; Shaw, D.P. Customary land tenure practices in ghana: Examining the relationship with land-use planning delivery. Int. Dev. Plan. Rev. 2013, 4, 21. [CrossRef]

65. Awuah KG, B.; Hammond, F.N.; Lamond, J.E.; Booth, C. Benefits of urban land use planning in Ghana. Geoforum 2014, 4, 37-46. [CrossRef]

66. Kuusaana, E.D.; Eledi, J.A. Customary land allocation, urbanization and land use planning in Ghana: Implications for food systems in the Wa Municipality. Land Use Policy 2015, 48, 454-466. [CrossRef]

67. GOG. Land Use and Spatial Planning Act; GOG: Warsaw, Poland, 2016.

68. Owusu, G. Small towns and decentralized development in Ghana: Theory and practice. Afr. Spectr. 2004, 4, 165-195.

69. Van der Molen, P. Some Measures to Improve Transparency in land Administration. 2007. Available online: http://www.fig.net/pub/fig2007/papers/ts_1a/ts01a_05_molen_1304.pdf (accessed on 18 August 2020).

70. Adiaba, S.Y. A Framework for Land Information Management in Ghana. Available online: https://wlv.openrepository.com/bitstream/handle/2436/332138/THESIS0920118doc.pdf?sequence= 1\&isAllowed=y (accessed on 2 March 2020).

71. Agbesi, S.; Tahiru, F. Application of Blockchain Technology in Land Administration in Ghana. In Cross-Industry Use of Blockchain Technology and Opportunities for the Future; IGI Global: Hershey, PA, USA, 2020; pp. 103-116. [CrossRef]

72. Mantey, S.; Tagoe, N.D. Geo-Property Tax Information System-A Case Study of the Tarkwa Nsuaem Municipality, Ghana. In Proceedings of the FIG Working Week, Rome, Italy, 6-10 May 2012; pp. 6-10.

73. Boamah, N.A. Constraints on property rating in the Offinso South Municipality of Ghana. Commonwealth J. Local Gov. 2013, 77-89. [CrossRef]

74. Awuah, K.G.B.; Hammond, F.N. Determinants of low land use planning regulation compliance rate in Ghana. Habitat Int. 2014, 4, 17-23. [CrossRef]

75. Siiba, A.; Adams, E.A.; Cobbina, P.B. Chieftaincy and sustainable urban land use planning in Yendi, Ghana: Towards congruence. Cities 2018, 4, 96-105. [CrossRef]

76. Goderdzishvili, N.; Gordadze, E.; Gagnidze, N. Georgia's Blockchain-powered Property Registration: Never blocked, Always Secured: Ownership Data Kept Best! In Proceedings of the 11th International Conference on Theory and Practice of Electronic Governance, Galway, Ireland, 4-6 April 2018; pp. 673-675. [CrossRef]

Publisher's Note: MDPI stays neutral with regard to jurisdictional claims in published maps and institutional affiliations.

(C) 2020 by the authors. Licensee MDPI, Basel, Switzerland. This article is an open access article distributed under the terms and conditions of the Creative Commons Attribution (CC BY) license (http://creativecommons.org/licenses/by/4.0/). 